\title{
PEMANFAATAN CITRA SATELIT QUICKBIRD UNTUK PEMETAAN POTENSI DAN KELAYAKAN TAMBANG BATUAN KAPUR (STUDI KASUS : KEC. SEMANDING, TUBAN)
}

\author{
Bangun Muljo Sukojo', Sep Hamdan Rif'anuddin ${ }^{2}$ \\ 1,2Departemen Teknik Geomatika, FTSLK-ITS, Kampus ITS Sukolilo, Surabaya, 60111, Indonesia \\ e-mail: ${ }^{1}$ bangun_ms@geodesy.its.ac.id
}

\begin{abstract}
Abstrak
Batu kapur merupakan salah satu barang tambang yang banyak terdapat di Indonesia. . Pegunungan kapur di Indonesia menyebar dari barat ke timur mulai dari pegunungan di Jawa Tengah hingga ke Jawa Timur, Madura, Sumatra dan Irian Jaya. Tuban berada dalam cekungan Jawa Timur bagian utara dan dimungkinkan sebagai wilayah potensial terdapatnya berbagai sumberdaya mineral, salah satunya adalah batuan gamping atau batuan kapur. Batu kapur di daerah Tuban tersebar di beberapa kecamatan, salah satunya yakni di kecamatan Semanding. Perlu dilakukan pemetaan potensi untuk mengetahui seberapa besar peluang untuk melakukan proses penambangan. Selain itu, perlu juga dilakukan nalisa mengenai kelayakan area untuk dilakukan penambangan. Hal ini perlu dilakukan karena berpengaruh terhadap nilai ekonomis penambangan. Proses pemetaan dilakukan dengan menggunakan data tutupan lahan kerapatan vegetasi dan geologi lapisan batuan di Kecamatan Semanding. Dari ketiga parameter dilakukan proses overlay dengan mempertimbangkan bobot setiap parameter. Berdasarkan hasil pengolahan, potensi kapur di kelaskan menjadi 5 kelas yakni potensi sangat rendah, rendah, sedang, tinggi, dan sangat tinggi. Hasil pengolahan data menunjukkan bahwa di Kecamatan Semanding memiliki potensi tinggi, dengan besaran prosentase 41\%. Pada pengolahan area layak tambang, didaptkan area seluas 5070.330 hektar potensi kapur layak tambang.
\end{abstract}

Kata kunci : Batu Kapur, Citra Satelit, Quickbird, Overlay, Layak Tambang

\begin{abstract}
Limestone is one of the mining material Indonesia. The limestone mountains in Indonesia spread from west to east from the mountains of Central Java to East Java, Madura, Sumatra and Irian Jaya. Tuban is located in the northern part of East Java basin and is possible as a potential area of various mineral resources, one of them is limestone or limestone rock. Limestone in the Tuban area spread in several districts, one of them is in the Semanding district. It needs to potential mapping to find out how much opportunity to do the mining process. In addition, there should also be an analysis on the feasibility study for area mining. This needs to be done because it affects the economic value of mining.

The potential mapping process is carried out using land cover data, vegetation density and rock layer geology in Semanding district. Meanwhile, the mineable area mapping is done with slope and road coverage. From the parameter do overlay process by considering the weight of each parameter. Then the mineable limestone potential map was obtained from the overlay of potential map data of limestone and mineable areas.

Based on the results of processing, limestone potential is classified into 5 classes, very low, low, medium, high, and very high potential. The results of data processing show that in Semanding district has a high potential, with a percentage of 41\%. While the potential of mineable lime is obtained an area of 5070,330 hectares that divided into classes, namely the potential is feasible mine, high potential worthy of the mine, and very high potential worthy of mine.
\end{abstract}

Key word : Limestone, Image satellite, Quickbird, Overlay, potential worthy of mine 


\section{PENDAHULUAN}

Indonesia. merupakan negara yang kaya akan barang tambang mineral dan logam. Batu kapur merupakan salah satu barang tambang yang banyak terdapat di Indonesia. Pegunungan kapur di Indonesia menyebar dari barat ke timur mulai dari pegunungan di Jawa Tengah hingga ke Jawa Timur, Madura, Sumatra dan Irian Jaya (Nowella 2017). Besarnya potensi tersebut juga diiringi dengan besarnya permintaan di masyarakat akan kebutuhan batu kapur karena batu kapur dapat digunakan untuk berbagai hal, dalam proses dengan fase tertentu baik langsung maupun tidak langsung, baik sebagai proses primer maupun sebagai bahan tambahan. Dengan besarnya kebutuhan tersebut, maka perlu usaha-usaha untuk medapatkan informasi mengenai dimana saja daerah yang berpotensi memiliki cadangan batu kapur yang besar. Selain itu, perlu juga dilakukan nalisa mengenai kelayakan area untuk dilakukan penambangan. Hal ini perlu dilakukan karena berpengaruh terhadap nilai ekonomis penambangan.

Salah satu daerah penghasil utama batu kapur di Jawa Timur, adalah Kabupaten Tuban. Berdasarkan letaknya, Tuban berada dalam cekungan Jawa Timur bagian utara dan dimungkinkan sebagai wilayah potensial terdapatnya berbagai sumberdaya mineral, salah satunya adalah batuan gamping atau batuan kapur (Majid 2017). Batu kapur di daerah Tuban tersebar di beberapa kecamatan, salah satunya yakni di kecamatan Semanding. Secara geografis kecamatan Semanding terletak di sebelah selatan kota Tuban dengan batas wilayah yakni sebelah utara berbatasan dengan kecamatan Tuban, sebelah timur berbatasan dengan kecamatan Palang, sebelah selatan berbatasan dengan kecamatan Plumpang dan kecamatan Grabagan, dan sedangkan sebelah barat berbatasan dengan kecamatan Merakurak.

Pada penelitian ini akan menggunakan teknologi penginderaan jauh citra setelit Quickbird. Data citra dapat menghasilkan parameter-parameter yang dibutuhkan dalam pengolahan data penelitian ini. Studi kelayakan jalan menggunakan data jalan dari Peta Rupa Bumi Indonesia skala $1: 25.000$. Hasil penelitian yang diperoleh dapat digunakan dalam penentuan cara penambangan dan perkiraan waktu yang dibutuhkan untuk melakukan usaha penambangan. Serta diharapkan dapat digunakan sebagai metode yang lebih cepat dan efisien dalam penentuan estimasi potensi batuan kapur.

\section{METODE}

\section{Lokasi Penelitian}

Lokasi penelitian ini dilakukan di Kecamatan Semanding Kabupaten Tuban, Jawa Timur dengan luas wilayah 1.209.800 Hektar dan secara geografis terletak pada koordinat $111^{\circ} 58^{\prime} 0^{\prime \prime}-112^{\circ} 8^{\prime} 45^{\prime \prime}$ BT dan $6^{\circ} 53^{\prime} 44^{\prime \prime}-7^{\circ} 1^{\prime} 24^{\prime \prime}$ LS.

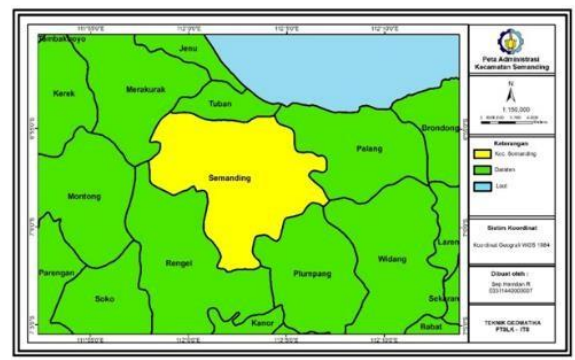

Gambar 1. Lokasi Penelitian

\section{Data dan Peralatan}

- Data

Data yang digunakan dalam penelitian ini Citra Quickbird 13 Oktober 2013 (sumber: Bappeda Tuban) Peta Geologi tahun 2008, Peta DEM SRTM 2017 dan Peta Digital RBI Skala 1:25.000 Lembar 1509-311

- Perangkat

Sedangkan peralatan yang digunakan meliputi perangkat keras berupa Laptop serta perangkat lunak pengolah data yang terdiri dari ArcGIS 10.4 serta Envi.

\section{Pengolahan Data}

1. Pengolahan Citra Quickbird

Koreksi yang digunakan pada pengolahan citra ada 2, yaitu koreksi geometrik dan koreksi radiometrik. Koreksi geometrik yaitu pembetulan citra secara geometrik sehingga proyeksi peta dan sistem koordinat yang digunakan sesuai dengan dunia nyata [3]. Koreksi radiometrik dilakukan untuk memperbaiki nilai piksel agar sesuai dengan yang seharusnya yang biasanya mempertimbangkan faktor gangguan atmosfer 
sebagai sumber kesalahan utama [4]. Koreksi radiometrik meliputi kalibrasi radiometrik dan koreksi atmosferik. Kalibrasi radiometrik adalah merubah atau mengkonversi nilai data citra asli hasil unduhan dari DN (Nilai Digital) ke nilai radian atau reflektan ToA (Top of Atmospheric). Koreksi atmosferik pada penelitian ini menggunakan metode FLAASH (Fast Line-of-sight Atmospheric Analysis of Spectral Hypercubes). Lalu melakukan pemotongan (cropping) untuk mendapatkan citra yang hanya meliputi daerah penelitian.

2. Pembuatan Peta Indeks Vegetasi

Pembuatan peta dilakukan dengan menggunakan algoritma NDVI pada citra, serta dilakukan klasifikasi dan pengharkatan. Untuk melihat kualitas dari data dilakukan uji korelasi dari Ground Truth NDVI dengan data insitu di lapangan dengan menggunakan kamera infrared. Hasil dari pengolahan dan ground truth harus memiliki nilai korelasi lebih sama dengan 0 dan kurang lebih sama dengan 1 . Pembuatan Peta Tutupan Lahan. Pembuatan peta berasal dari data citra Quickbird, dimana dilakukan dengan menggunakan metode supervised classification : maximum likelihood, serta menghitung matriks konfusi. Ketelitian yang dihasilkan harus lebih besar dari $85 \%$ untuk memenuhi toleransi.

3. Overlay

Dalam proses overlay, perlu dilakukan skoring terlebih dahulu. Skoring bertujuan untuk memberikan nilai pada setiap parameter yang dimiliki. Setelah dilakukan skoring maka dilakukan proses overlay pada empat peta yang telah dilakukan pengharkatan yakni peta tutupan lahan, peta indeks vegetasi dan peta geologi. Overlay beberapa peta menghasilkan suatu informasi baru dalam bentuk luasan atau poligon yang terbentuk dari irisan beberapa poligon dari peta-peta tersebut.

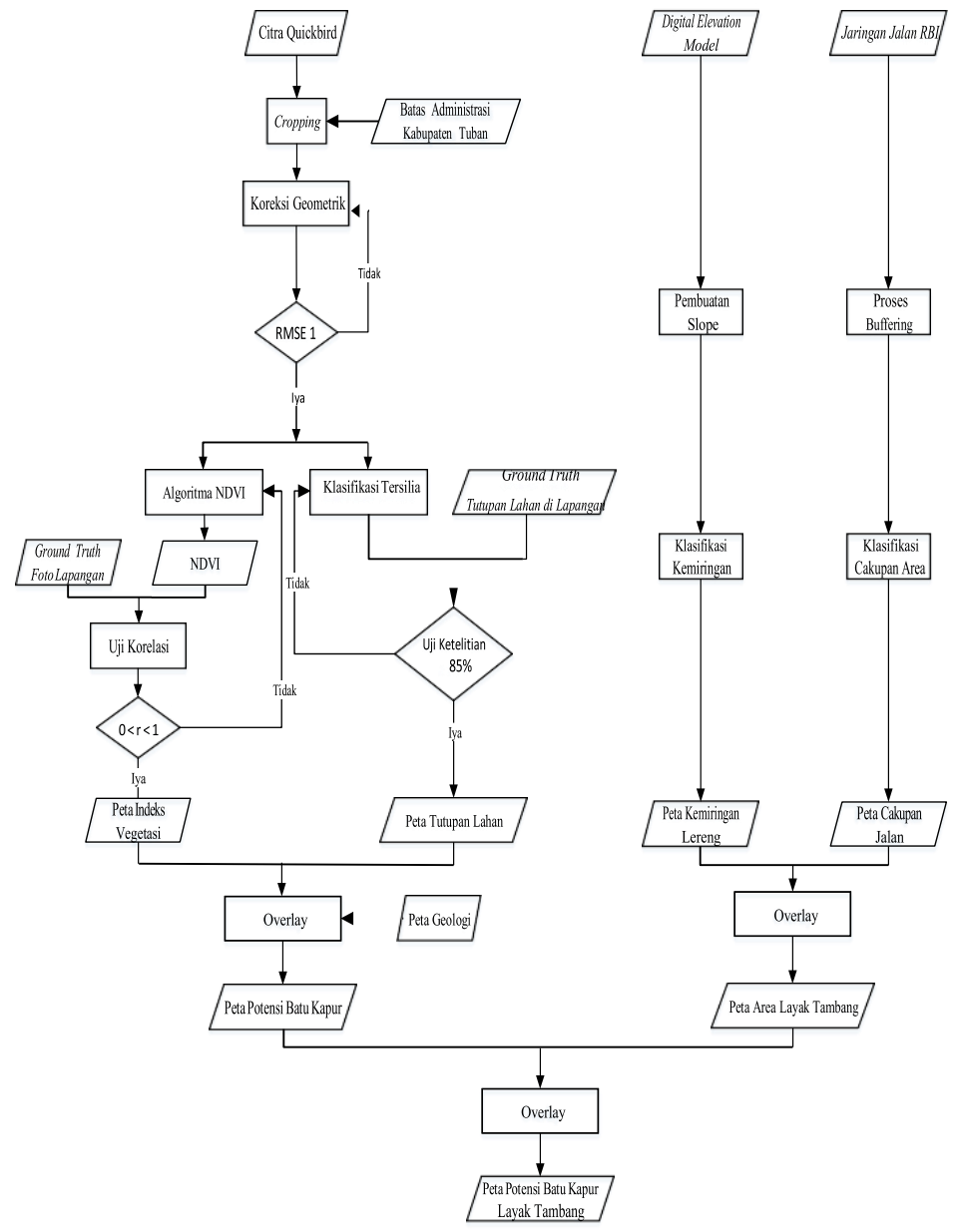

Gambar 2. Diagram Alir Pengolahan Data

\section{HASIL DAN PEMBAHASAN}

\section{Koreksi Geometrik}

Proses koreksi geometrik merupakan proses pembenaran lokasi dari setiap pixel terhadap kondisi sebenarnya di lapangan. Pixel yang tidak sesuai lokasi perlu dibenarkan karena jika terdapat kesalahan pada data awal, maka data yang dihasilkan tidak dapat dipertanggung- jawabkan hasilnya terhadap lokasi yang sebenarnya.

Pada penelitian ini, proses koreksi geometric menggunakan data Ground Control Point (GCP) yang diukur dengan menggunakan GPS Geodetik. Peralatan yang digunakan harus memiliki ketelitian yang tinggi untuk medapatkan hasil yang baik, dimana batasan toleransi kesalahan geometric adalah 1 pixel. 


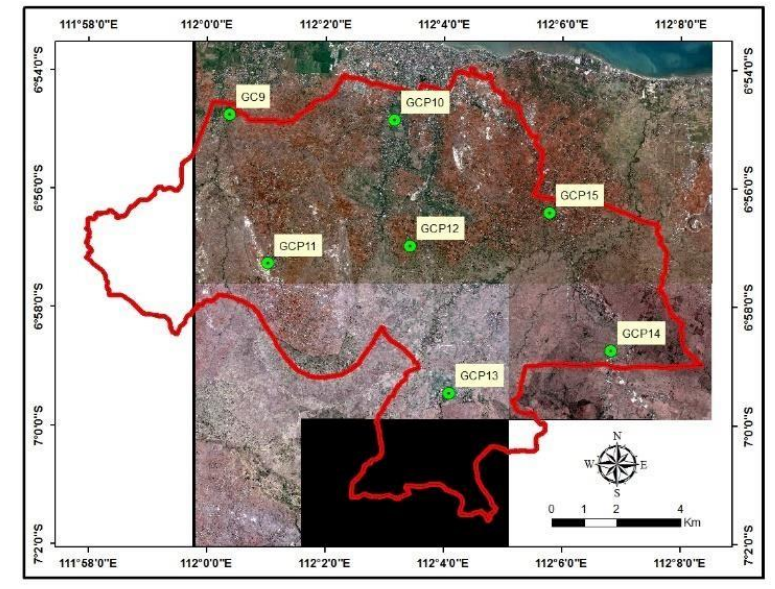

Gambar 3. Sebaran Titik GCP

Proses pengukuran GCP dilakukan setelah perencanaan telah diperhitungkan secara matang. Proses pengukuran menggunakan metode differential radial. Metode ini menggunakan 1 titik sebagai acuan koordinat yang sudah benar, dan rover digunakan untuk mengukur titik yang tidak diketahui koordinatnya.

Data yang diapatkan dari pengukuran GCP digunakan untuk melakukan proses koreksi geometrik. Proses ini dilakukan dengan software pengolah citra. Pada proses koreksi geometrik, koordinat horizontal dari data lapangan dimasukan sesuai lokasi titik ukurannya di lapangan. Dari proses ini dihasilkan data berupa nilai $R M S e$. Nilai RMSe memiliki toleransi sebesar 1 pixel. Data yang didapatkan memiliki $R M S$ sebesar 0.33 sehingga data citra satelit telah terkoreksi secara geometrik dan dapat digunakan untuk melakukan proses selanjutnya.

\section{Klasifikasi Tutupan Lahan}

Klasifikasi Citra merupakan proses yang berusaha mengelompokkan seluruh pixel pada suatu citra ke dalam sejumlah class (kelas), sedemikian hingga tiap kelas merepresentasikan suatu entitas dengan properti yang spesifik. Data yang digunakan proses klasifikasi ini adalah data citra satelit yang telah melalui proses mozaiking, koreksi geometrik, koreksi radiometrik, dan cropping.

Pembagian kelas menggunakan aturan SNI 7645:2010 skala 1:50.000. Dalam proses ini kelasnya adalah permukiman, sawah, badan air, semak belukar, lahan terbuka/tegalan. Setiap kelas mewakili settiap unsur yang berbeda. Proses klasifikasi dilakukan menggunakan software pengolah citra dengan menggunakan metode Supervised Classification : Maximum Likelihood dimana metode ini mengasumsikan bahwa statistik untuk setiap kelas di masing-masing band yang terdistribusi secara normal dan menghitung probabilitas bahwa setiap pixel yang diberikan milik kelas tertentu.

Berdasarkan hasil pengolahan data, didapatkan hasil Peta Tutupan Lahan seperti gambar berikut. Terdapat area yang tidak terklasifikasi karena area tersebut tidak tercakup dalam citra yang tersedia.

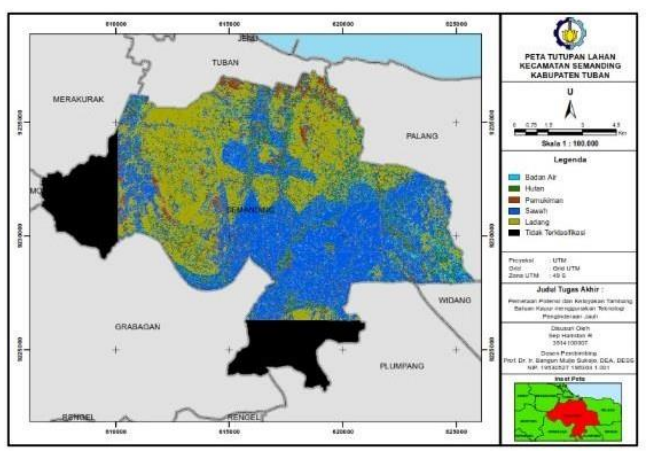

Gambar 4. Peta Tutupan Lahan

Peta tutupan lahan yang mewakili 5 kelas memiliki luasan yang berbeda. Luasan paling besar adalah tutuppan kelas sawah dan paling sempit adalah kelas kelas perairan. Berikut ini adalah hasil luasan setiap kelas dari hasil pengolahan klasifikasi

Tabel 1. Luas Hasil Tuitupan Lahan

\begin{tabular}{cc}
\hline Objek & Luas (hektar) \\
\hline Badan Air & 550,168 \\
Hutan & 818,796 \\
Pemukiman & 930,133 \\
Sawah & 4741,869 \\
Tegalan & 3893,272 \\
\hline
\end{tabular}

Tutupan lahan merupakan salah satu factor yuang mempengaruhi terbentuknya karst. Semakin besar kadar $\mathrm{CO}_{2}$ yang terkandung semakin tinggi daya larut air terhadap batu gamping dimana pada hutan yang lebat memiliki kandungan $\mathrm{CO}_{2}$ yang melimpah akibat dari hasil perombakan sisa-sisa organik (dahan, ranting, daun, bangkai binatang) oleh mikro organisme.

Hasil pengolahan tutupan lahan perlu dilakukan proses uji ketelitian. Uji ketelitian tutupan lahan dilakukan dengan menggunakan uji confussion 
matrix. Untuk melakukan uji, perlu dilakukan sampling data tutupan lahan langsung di lapangan.

Dari hasil keseluruhan didapatkan overall accuracy sebesar $88.608 \%$ yang dapat memenuhi toleransi minimum yakni $85 \%$. Hasil klasifikasi dapat dikatakan benar berdasarkan hasil uji ketelitian sehingga proses pengolahan dapat dilanjutkan.

\section{Peta Kerapatan Vegetasi}

Indeks vegetasi merupakan saluran spektral yang menjadi salah satu indikator untuk mengetahui tingkat kekeringan lahan dan mengukur tingkat kehijauan atau kerapatan vegetasi pada suatu wilayah.

Dalam proses pengolahan peta ini, data yang digunakan adalah data citra satelit yang telah melalui proses mozaiking, koreksi geometrik, koreksi radiometrik, dan cropping. Dimana pengolahannya menggunakan algortima NDVI (Normalized Difference Vegetation Index) yang menggunakan band kanal merah dan infrared pada citra satelit.

Pengolahan data citra satelit terkoreksi menghasilkan data dengan rentang indeks maksimal sebesar -0.979210 , minimal sebesar 0.929412 , dan rata-rata sebesar 0.349693 . Berikut ini adalah gambar hasil pengolahan data peta kerapatan tutupan lahan.

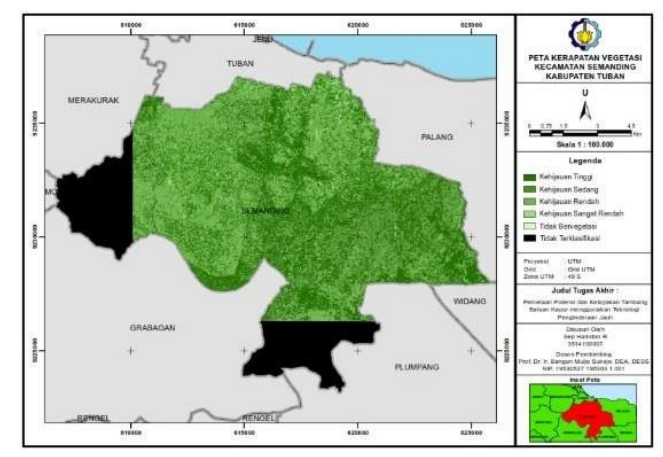

Gambar 5. Peta Kerapatan Vegetasi

Dari data hasil pengolahan juga didapatkan luasan area untuk setiap kelasnya. Kelas yang memiliki area paling luas adalah kelas 1 dan yang paling kecil adalah kelas 5 .
Tabel 2. Luas Kelas Keparatan Vegetasi

\begin{tabular}{cc}
\hline Kelas & Luas (hektar) \\
\hline Kelas 1 & 4412,003 \\
Kelas 2 & 2999,808 \\
Kelas 3 & 3301,850 \\
Kelas 4 & 280,903 \\
Kelas 5 & 0.068 \\
\hline
\end{tabular}

Jika ditinjau dari parameter kerapatan vegetasi, salah satu syarat terbentuknya kawasan karst (dengan dominasi batu kapur dan dolomit) adalah memiliki vegetasi penutup lahan dengan kerapatan tinggi. Namun ketika dilakukan pengolahan di citra dan pengecekan dilapangan di dapatkan hasil bahwa indeks vegetasi yang ada di lokasi tambang batu kapur tersebut masuk dalam tipe kerapatan vegetasi yang jarang (range -1 sampai 0,32 ). Hal tersebut dikarena lokasi tambang yang ada sudah berubah menjadi dari semak belukar menjadi ladang/tegalan. Range - 1 sampai 0.32 memiliki luasan paling besar dalam pembagian tipe indeks vegetasi yaitu 8374,6 hektar.

Hasil klasifikasi indeks vegetasi yang dilakukan perlu dilakukan uji korelasi dengan data lapangan untuk menjamin bahwa data yang didaptkan secara penginderaan jauh dapat dipercaya.

Proses uji korelasi dilakukan dengan menggunakan kamera yang dilengkapi dengan sensor infra merah, dimana hasil pemotretan dari kamera tersebut dapat diohitung nilai NDVI sehingga dapat dilakukan proses perhtiungan uji korelasi.

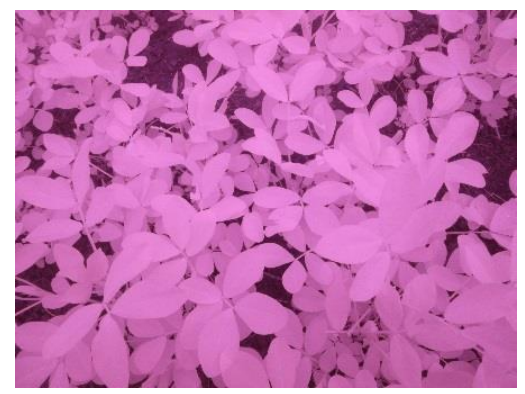

Gambar 6. Hasil Kamera Infrared

Berdasarkan data lapangan yang dioalah, didapatkan nilai uji korelasi sebesar 0.6951 dimana hasil tersebut tergolong dalam nilai yang kuat. Berikut ini adalah gambaran dari uji klasifikasi yang dilakukan. 


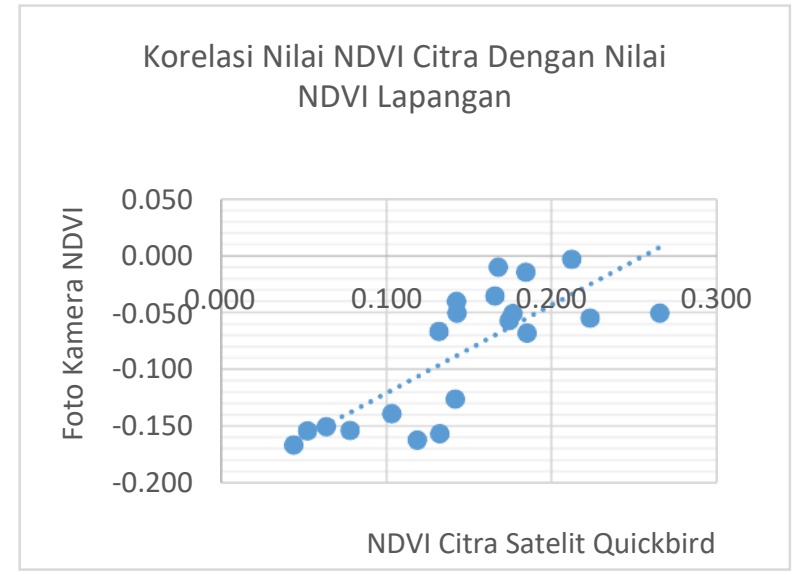

Gambar 7. Grafik Korelasi NDVI Citra dan data insitu

Dalam hasil pengolahan data, didapatkan rata-rata hasil NDVI dari data insitu menghasilkan nilai negatif dengan rata-rata nilainya adalah 0,086. Data insitu di lapangan berupa objek vegetasi, sedangkan hasil rata-rata NDVI menunjukkan bahwa objek yang dideteksi adalah tidak termasuk kategori vegetasi. Nilai NDVI yang dihasilkan perlu dilakukan analisa lebih lanjut mengenai kamera yang digunakan. Kalibrasi nilai NDVI perlu dilakukan untuk menjamin nilai NDVI hasil insitu. Meskipun data korelasi yang dihasilkan kuat, hasil insitu tidak dapat dipercaya.

\section{Peta Geologi}

Peta geologi merupakan ppetunjuk tentang susunan lapisan batuan yang memberikan informasi mengenai formasi apa saja yang terdapat pada suatu daearah.

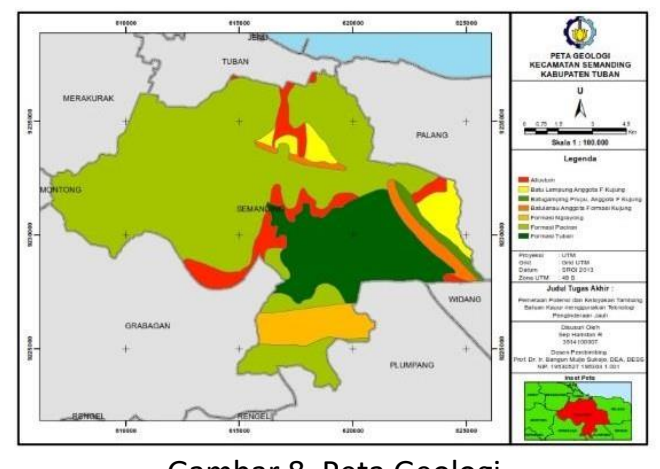

Gambar 8. Peta Geologi

Berdasarkan data yang digunakan, yakni Peta Geologi Lembar Jatirogo didapatkan 7 fomasi. Formasi-formasi tersebut adalah sebagai berikut :
Tabel 3. Luas Formasi Batuan

\begin{tabular}{|c|c|}
\hline Batuan Penyusun & Luas(ha) \\
\hline Alluvium & 879.5 \\
\hline $\begin{array}{l}\text { Batulempung Anggota F. } \\
\text { Kujung }\end{array}$ & 370.2 \\
\hline $\begin{array}{l}\text { Batugamping Prupu, Anggota } \\
\text { F. Kujung }\end{array}$ & 8085.9 \\
\hline Batulanau Anggota F. Kujung & 703.6 \\
\hline Formasi Ngrayong & 548.8 \\
\hline Formasi Paciran & 189.5 \\
\hline Formasi Tuban & 2328.2 \\
\hline
\end{tabular}

\section{Peta Potensi Batuan Kapur}

Peta potensi batuan merupakan peta hasil pengolahan dari 3 parameter, yakni ppeta tutupan lahan, peta kerapatan vegetasi, dan peta geologi. Dari ketiga data tersebut dilakukan pproses overlay dengan menggunakan software pengolah citra.

Hasil dari proses intersect didapatkan seperti gambar 7. Pada hasil tersebut, didapatkan hasil dengan kelas dengan area terluas adalah kelas sawah dengan luas 4741,9 hektar dan kelas paling sempit adalah kelas perairan dengan luasan 550.2 hektar.

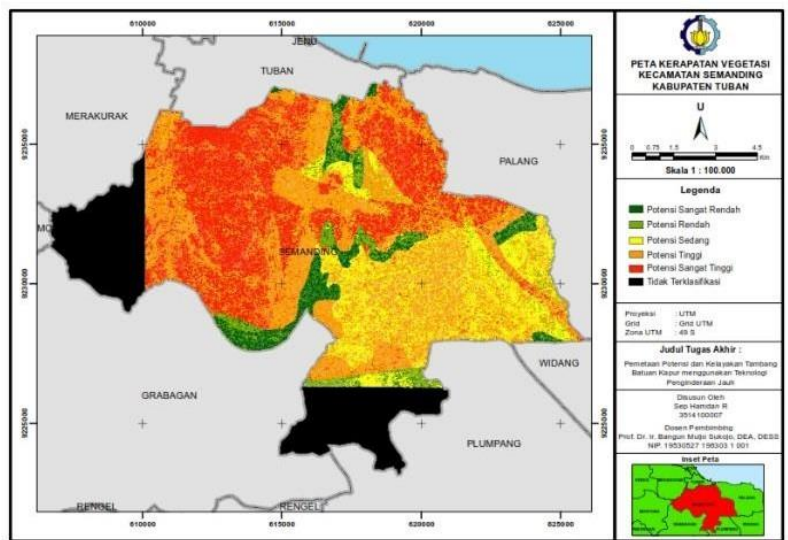

Gambar 9. Peta Potensi Batu Kapur

Pada hasil intersect pada gambar tersebut, didapatkan hasil dengan kelas dengan area terluas adalah kelas potensi tinggi dengan luas 4579,654 hektar dan kelas paling sempit adalah kelas potensi sangat rendah dengan luasan 536,169 hektar. Untuk luasan kelas yang lain dijabarkan pada tabel dibawah ini: 
Tabel 4. Luas Potensi Batu Kapur

\begin{tabular}{cc}
\hline Kelas & Luas (hektar) \\
\hline Potensi Sangat Rendah & 536.170 \\
Potensi Rendah & 562.849 \\
Potensi Sedang & 2108.180 \\
Potensi Tinggi & 4579.654 \\
Potensi Sangat Tinggi & 3203.469 \\
\hline
\end{tabular}

\section{Peta Area Layak Tambang Batu Kapur}

Peta Area Kelayakan merupakan peta yang menggambarkan daerah mana yang memiliki area yang layak untuk ditambang. Peta ini ditentukan atau dibuat dengan menggunakan dua parameter, yakni data peta cakupan jalan dan peta kelerengan. Jaringan jalan merupakan system prasarana utama yang menjadi bagian dari system jaringan transportasi darat. Jaringan jalan disebut juga sebagai tonggak penggerak perekonomian wilayah., karena dapat meningkatkan pertumbuhan perekonomian wilayah.

Dalam menentukan kelayakan jalan untuk tambang, perlu dibuat peta untuk cakupan jalan yang ada di Kecamatan Semanding. Dalam pengolahan peta cakupan jalan, data jaringan jalan dilakukan proses buffer untuk mengetahui cakupan areanya.

Dalam peta ini, terdapat pembagian kelas untuk cakupan luasannya. Berikut ini adalah pembagian kelasnya :

Tabel 5. Pembagian Kelas Cakupan Jalan

\begin{tabular}{cc}
\hline Kelas & Cakupan \\
\hline Kelas 1 & $0-500 \mathrm{~m}$ \\
Kelas 2 & $500-1000 \mathrm{~m}$ \\
Kelas 3 & $1000-2000 \mathrm{~m}$ \\
Kelas 4 & $>2000 \mathrm{~m}$ \\
\hline
\end{tabular}

Berikut ini adalah hasil dari proses buffering dari data jaringan jalan di Kecamatan Semanding.

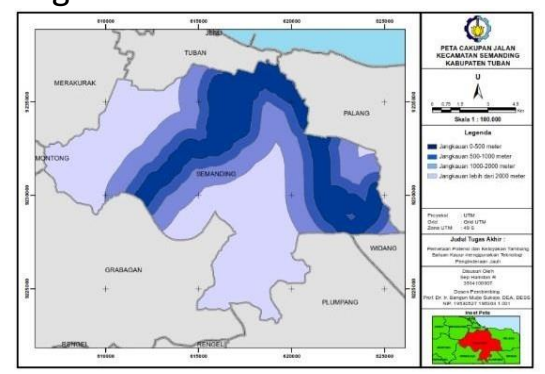

Gambar 10. Peta Cakupan Jalan
Tabel 6. Luasan Cakupan Jalan

\begin{tabular}{cc}
\hline Kelas & Luas (hektar) \\
\hline Kelas 1 & 8971.814 \\
Kelas 2 & 3063.532 \\
Kelas 3 & 1060.235 \\
Kelas 4 & 10.111 \\
\hline
\end{tabular}

Dalam hasil pengolahan tersebut, jalan dengan cakupan kelas 1 adalah yang paling dominan dimana kelas 1 memiliki luasan 8971.814 hektar. Kemiringan lereng merupakan sudut yang dibentuk oleh perbedaan tinggi permukaan lahan (relief), yaitu antara bidang datar tanah dan bidang horizontal, dan dihitung dengan prosentase. Suatu lereng mengalami gerakan karena kestabilan tanah/batuan pada lereng tersebut terganggu, baik oleh berbagai proses yang berasal dari dalam ataupun dari luar.

Peta kelerengan dibuat menggunakan data dem. Data dem yang digunakan mencakup keseluruhan area di kecamatan Semanding. Data dem diproses menjadi data slope, kemudian dilakukan proses kreklasifikasi. Klasifikasi dari peta kemiringan didasarkan atas penelitian terdahulu oleh Suryana 2011 . Berikut ini adalah pembagian kelasnya :

Tabel 7. Pembagian Kelas Kemiringan Lereng

\begin{tabular}{cc}
\hline Kelas & Kemiringan $(\%)$ \\
\hline Kelas 1 & $0-8$ \\
Kelas 2 & $8-15$ \\
Kelas 3 & $15-40$ \\
Kelas 4 & $>40$ \\
\hline
\end{tabular}

Berikut ini adalah hasil pengolahan data dem yang menghasilkan peta kemiringan lereng. Peta ini memiliki skala 100.000 dengan area yang paling dominan adalah kelas 4 dengan luas 3972,416 hektar dan area yang paling sempit adalah kelas 5 dengan luasan 425,749 hektar.

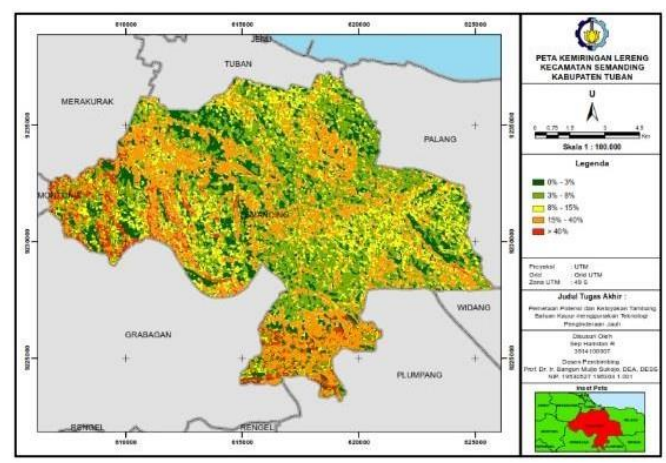

Gambar 11. Peta Kemiringan Lereng 
Proses pembuatan peta area kelayakan menggunakan metode intersect. Metode intersect dilakukan dengan generate dua data parameter yang diolah sebelumnya. Hasil proses skoring dan intersect didapatkan Peta Area Layak Tambang, dimana berdasarkan parameter fisiknya, area Semanding dominasi oleh area pada kelas tidak layak dengan luas area 7627,591 hektar dan area yang layak ditambang memiliki luasan 5478,100 hektar. Nilai luas yang dihasilkan berdasarkan dua parameter yang digunakan dalam proses overlay. Berikut ini adalah gambaran hasil proses pengolahan data yang dilakukan.

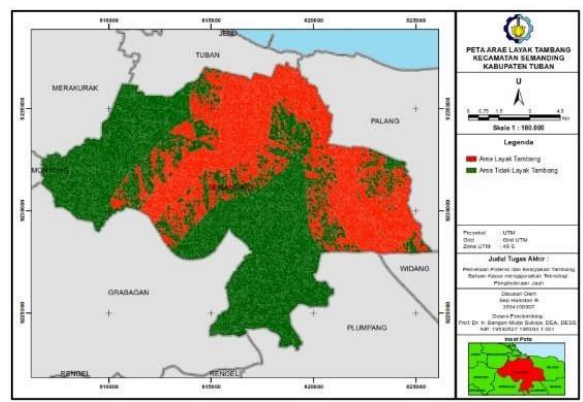

Gambar 12. Peta Area Layak Tambang

\section{Peta Potensi Batu Kapur Layak Tambang}

Peta ini menggambarkan area yang layak untuk ditambang berdasarkan potensi dan area yang layak ditambang. Data yang digunakan pengolahan adalah data peta potensi dan peta area layak tambang.

Proses pengolahan dilakukan dengan metode clipping. Metode clipping membutuhkan data input dan data batas pemotong. Data input yang digunakan adalah peta potensi batu kapur, sedangkan untuk pemotongnya adalah peta area layak tambang.

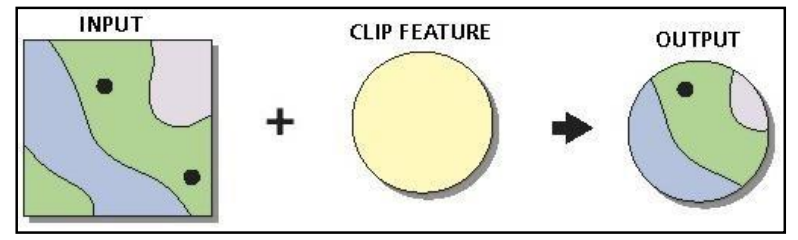

Gambar 13. Metode Clipping

Hasil dari proses clipping didapatkan berupa peta potensi layak tambang yang dibagi menjadi 3 kelas, yakni potensi sedang layak tambang, potensi tinggi layak tambang, dan potensi sangat tinggi layak tambang. Dari data hasil didapatkan kelas yang paling dominan adalah kelas potensi tinggi layak tambang dengan luasan area 2227.757 hektar.

Berikut ini adalah hasil luasan dan peta layak tambang.

Tabel 8. Luas Potensi Batu Kapur Layak Tambang

\begin{tabular}{cc}
\hline Kelas & Luas (hektar) \\
\hline Potensi Sedang Layak Tambang & 937,895 \\
Potensi Tinggi Layak Tambang & 2227,757 \\
Potensi Sangat Tinggi Layak Tambang & 1904,677 \\
\hline
\end{tabular}

Hasil Peta Potensi Layak Tambang diwakili oleh 3 kelas, yakni potensi sedang layak tambang, potensi tinggi layak tambang, dan potensi sangat tinggi layak tambang. Gambar 12 adalah gambar peta hasil pengolahan data yang telah dilakukan.

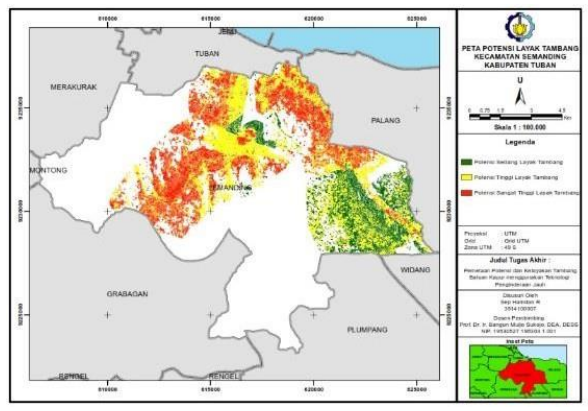

Gambar 14. Peta Potensi Layak Tambang

Hasil yang didapatkan dari pengolahan perlu dilakukan pengujian dilapangan. Untuk melihat tingkat akurasi dari hasil penelitian, dilakukan pengambilan titik sampel penambangan di Kecamatan Semanding. Peneliti terjun ke lapangan untuk mengambil sampel lokasi tambang batu kapur.

Berdasarkan dari hasil overlay, terdapat 10 titik sesuai dengan data peta potensi layak tambang dan 1 titik tidak sesuai. Dapat dikatakan tingkat akurasi dari hasil uji adalah $90.9 \%$ sesuai. Berikut ini adalah gambar dari overlay dari data sampel dan peta potensi layak tambang.

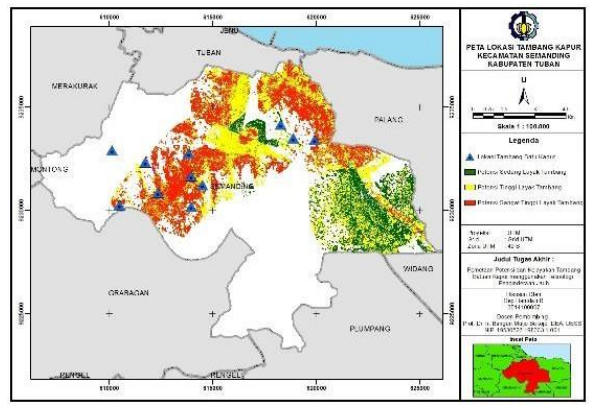

Gambar 15. Peta Lokasi Tambang 


\section{KESIMPULAN}

Kesimpulan yang dapat diambil berdasarkan analisis terhadap hasil penelitian tentang pemetaan potensi batu kapur dengan teknologi penginderaan jauh ini sebagai berikut :

a. Kecamatan Semanding memilki potensi kapur yang tinggi dimana terdapat 4579.654 hektar lahan dalam kelas potensi tinggi. Secara keseluruhan, hasil pengolahan data menunjukkan dimana pada kelas sangat rendah memiliki luas 536.170 hketar, kelas spotensi rendah memiliki luas 562.849, kelas potensi sedang memiliki luas 2108.180 hektar, potensi tinggi luas 4579.654 hektar, dan potensi sangat tinggi luas 3203.469 hektar

b. Kecamatan Semanding memiliki area potensi layak tambang dengan luasan 5070.330 hektar. Hasil tersebut terbagi dalam 3 kelas, kelas potensi sedang layak tambang dengan luas 937.895 , kelas potensi tinggi layak tambang dengan luas 2227.757 , dan kela potensi sangat tinggi layak tambang dengan luas 1904.677

\section{UCAPAN TERIMA KASIH}

Penulis mengucapkan terima kasih kepada Bappeda Kabupaten Tuban atas dukungan data dan kemudahan selama penelitian ini berlangsung.

\section{DAFTAR PUSTAKA}

Abidin, H, Z. 2002. Penentuan Posisi dengan GPS dan Aplikasinya. Jakarta: PT Pradnya Paramita.

Danoedoro, Projo. 1996. Pengolahan Citra Digital. Yogyakarta : Fakultas Geografi. Universitas Gadjah Mada.

Majid, D. A., 2017. "Pemetaan Potensi Batuan Kapur menggunakan Metode Penginderaan Jauh dan Sistem Informasi Geografis di Kabupaten Tuban". Laporan Tugas Akhir. Surabaya: Institut Teknologi Sepuluh Nopember.

Novella, M. S., 2017. "Identifikasi Batu Kapur Berdasarkan Tekstur menggunakan Metode Learning Vector Quantization". Yogyakarta: Universita Mercu Buana.
Soenarmo, S. H., 2009. Penginderaan Jauh dan Pengenalan Sistem Infromasi Geografi Untuk Bidang IImu Kebumian. Bandung : Institut Teknologi Bandung (ITB). 